\title{
$\sqrt{J}$
}

\section{Why Children Obey the Law: Rethinking Juvenile Justice and Children's Rights in Europe through Procedural Justice}

Youth Justice 2018, Vol. 18(I) 34-51 (C) The Author(s) 2018 Reprints and permissions: sagepub.co.uk/journalsPermissions.nav DOI: 10.1 | $77 /|4732254| 774 \mid 225$ journals.sagepub.com/home/yij

@SAGE

\section{Maria José Bernuz Beneitez and Els Dumortier}

\begin{abstract}
This article explores how the idea of procedural justice can help us to rethink juvenile justice and research children's rights in Europe differently. To frame the following argument, we will question four implications of the procedural justice perspective: I) the need to implement rights and not just proclaim them, 2) the need to investigate a 'double perspective' on children's rights implying both juvenile justice professionals and children in conflict with the law, 3) the child's right to effectively participate and be involved in the process and 4) the idea that age matters in the judicial reaction to crime. The resulting conclusions and discussions revolve around the scientific consequences and challenges we must face when we take procedural justice perspective seriously.
\end{abstract}

\section{Keywords}

juvenile justice, procedural justice, children's rights, legitimation

\section{Introduction}

The Convention on Children's Rights of the United Nations (UN CRC, 1989) has been ratified by all European countries and has managed to strengthen the culture of children's rights on the (specifically Western) European level. However, after 25 years of UN CRC, the results can not be called successful. According to Liefaard and Sloth-Nielsen "there is cause both to celebrate the CRC's success as well as lament its failure to safeguard the rights of all children regardless of where they live or find themselves" (Liefaard \& SlothNielsen, 2016, 2-3). Also, in the area of juvenile justice, violations of children's rights are omnipresent and some authors suggest that during the last decade one cannot observe a standstill, but on the contrary a regressive movement can be discerned (Goldson \& Muncie, 2015). Even Liefaard $(2015,236)$ wonders to what extent children's rights "can contribute to a common (or universal) understanding of a child rights oriented juvenile 
justice system". Also, during the International Conference on 25 years Convention of the Rights of the Child numerous experts claimed that more efforts need to be made to fully implement children's rights and that there is a need to set out an ambitious research agenda on children's rights for the next 25 years (Liefaard \& Sloth-Nielsen, 2016). Clearly, the children's rights movement in Europe is in need of redirection.

This contribution aims at rethinking juvenile justice and children's rights in Europe in order to make both more acknowledged and efficacious. We uphold that a procedural justice perspective can help us (start to) rethink children's rights and render juvenile justice in Europe more legitimate for children in conflict with the law, in addition to the many professionals involved. Legitimation means a greater impact.

We will first investigate 'the rise and fall' in Europe of the "empowering" children's rights movement that tried to supplant classic "paternalistic" juvenile justice. Secondly, we will elaborate on the procedural justice perspective as developed by scholars such as Tom Tyler, though later fostered in Europe by (Anglo-Saxon) scholars such as Bottoms and Tankebe. In the third and final section, we will question four important implications of contemporary procedural justice perspective to render juvenile justice and children's rights in Europe more legitimate: 1) the need to implement rights (not just proclaim them), 2) the need to investigate a 'double perspective' on children's rights implying both power holders (or professionals of juvenile justice) and citizens (or children in conflict with the law), 3) the child's right to effectively be involved and participate in the judicial process and 4) the idea that feelings and perceptions of justice are 'developed' throughout life and that, as a consequence, age does and must matter in judicial reactions to crime and during the decision-making process.

In the conclusion, we will defend the idea that to better understand juvenile justice and children's rights in addition to the way they function, there is - following a procedural justice perspective - an urgent need of additional varied empirical insights.

\section{The 'rise and fall' of children's rights in Europe?}

In European juvenile justice debates, the birth of the UN CRC (1989) is often presented as an outcome of the Children's Rights Movement and the plea for more legal rights and procedural safeguards for children in conflict with the law. Indeed, at the beginning of the twentieth century in many western countries the Child Saving Movement led to the implementation of a child protection system and classical safeguards were overturned to meet the needs of the child (Junger-Tas \& Decker, 2006). However, after World War II and more specifically from the 1960 's on, child saving practices and discourses became heavily criticised for at least two main reasons.

\section{The children's rights movement}

On the one hand, the child's legal position and participation in juvenile justice procedures and outcomes became heavily criticised, as in the child care systems the child was reduced to a mere object of interventions. Verhellen, a famous Belgian children's rights advocate, claimed that child protection laws reduced children to "objects of law" (Verhellen, 2000), 
because the legal interventions were steered and decided by experts (judges, probation officers, educators, etc.) who knew what was best for the child. After all, their expertise stemmed from their professionalism and specialism, but furthermore from their adult status. The child had little to say in these decision-making processes that largely depended on the discretion of the adult experts involved (Christiaens, 2015).

However, in the 1960's, when authority and paternalism became heavily criticised, classic child protection systems came under pressure. As a counterreaction, a critical children's rights movement emerged from the 60's onward, both in the United States (of Americas) and in Europe, claiming that children (and their rights) should be taken seriously. According to Verhellen (2000) children are actual human beings and should therefore be approached as true "subjects of rights" (or holders of rights) instead of "objects of law". This implies that children must be heard and that they must be able to participate in the juvenile justice process. Clearly this children's rights movement and its changing image on the place and the role of the child in juvenile justice procedures came together with the changing images of childhood in the Western World (Veerman, 1992; Fass, 2013).

Besides this changing image, a second major criticism to child protection also started flourishing during the 1960's. Even though the argument was not innovative, questioning the regenerative and educational merits of the 'protectional' and or child 'care' measures as well as the juvenile courts clearly gained weight at that time (Platt, 1966;1977; Donzelot, 1979). In Belgium, Van de Kerchove described this as the 'mystifying forces' of welfare language and therefore concluded that 'welfare measures' were in fact 'repressive measures' which were not called repressive in order to 'free' the state from its constitutional duties to anticipate legal rights and procedural guarantees (Van de Kerchove, 1977). According to Rush, "radical criminologists have delighted in discovering control beneath the mask of benevolence" $(1992 / 2002,140)$.

Both in Europe and the Unites States, the high courts have similarly integrated this two-folded criticism on child protection systems (namely the lack of rights and the lack of welfare) in some of their important verdicts on juvenile justice practices. Already in 1966, the US Supreme Court stated in Kent v. United States that 'there are reasonable grounds to believe that the child receives the worst of both worlds, that it gets neither the solicitous care and regenerative treatment postulated for children, nor the protections accorded to adults'. Additionally, in re Gault (1967) the US Supreme Court held that juveniles accused of crimes in a delinquency proceeding must be afforded many of the same due process rights as adults, such as the right to counsel, the right to confront witnesses, and the rights against self-incrimination.

In the case of Bouamar v. Belgium (1988), the European Court of Human Rights declared that locking up a juvenile in an adult prison cannot be seen as an educational measure. Moreover, certain classical procedural rights, like the right to lodge an appeal and the right to be heard, were violated. The European Court went a step further in the case of T. v UK (Bulger case) and recognized that the right of the child to participate in the trial was part of the right to a fair trial and indicated that "it is essential that a child charged with an offence is dealt with in a manner which takes full account of his age, level of maturity and intellectual and emotional capacities, and that steps are taken to promote his ability to understand and participate in the proceedings"1. 


\section{The influence of children's rights in Europe}

With the arrival of the UN CRC in 1989 and the introduction of art. 12 (the right to be heard), art. 37 (on detention and punishment of children) and art. 40 (on juvenile justice), a historic breakthrough seemed to be taking place. Children committing crimes would no longer be treated as "objects" but as real "subjects" whose rights should be respected and who should be involved in the judicial process. Indeed, from the 1990's on, all European countries signed the UN CRC and though not all European countries fully incorporated the UN CRC into domestic law, integration of the CRC principles into domestic law was and is steadily taking place (Lundy, Kilkelly a.o., 2012, 4). The convention was further explained and implemented in Europe by way of the concluding (and often quite critical) Observations of the UN Committee on the Rights of Child vis-à-vis the European state parties $^{2}$ and through General Comments such as the GC $\mathrm{n}^{\circ} 10$ on children's rights in juvenile justice (2007) and the $\mathrm{GC} \mathrm{n}^{\circ} 12$ on the right to be heard (2009). As Liefaard (2016, 911) points out very aptly: "There has been cross-fertilization between international children's rights standards and the case law of the European Court of Human Rights with regard to the legal status of children".

The Committee of Ministers of the Council of Europe furthermore created the Guidelines on Child Friendly Justice (2010), that are intended to enhance children's access to justice and their treatment. These guidelines set out basis rules for European states to follow when adapting their justice systems to the specific needs of children. According to these guidelines "child friendly" justice is justice that is accessible, age appropriate, speedy, diligent, adapted to and focused on the needs of the child, respecting the right to due process, to participate in proceedings and the right to integrity and dignity.

Finally, also in the European Union, children's rights in juvenile justice became a hot topic, which led to the recent, new and legally binding Directive on procedural safeguards for children suspected or accused in criminal proceedings (European Parliament \& European Council, 2016).

However, the UN CRC and the children's rights movement in Europe were themselves criticised for at least three major reasons. First of all, and notwithstanding its nearly universal attraction, the UN CRC is claimed to be one of the most violated conventions in the world (Goldson \& Muncie, 2015). The weak control mechanisms and the fact that some countries easily provide "lip service to children's rights simply to be granted recognition as a "modern developed state" (Muncie, 2009), are some of the main causes of this problem.

Moreover, it is worth wondering whether the merits of the UN CRC are not taken too much and too easily for granted. Granting rights in universal conventions, in European directives and guidelines and in domestic laws is not the same as reflecting on the purpose and meaning of children's rights, nor observing or experiencing them in daily practice. Following this train of thought, and even though we can witness an increasing interest in processes of children's rights implementation ${ }^{3}$, more qualitative scientific research on how children's rights shape juvenile justice practices and how they are actually experienced is needed (Kilkelly \& Lundy 2006; Goodwin-De Faria \& Marinos 2012; Christiaens, 2015; De Graaf, Christiaens \& Dumortier, 2016). Consequently, there is little understanding of why and how children's rights are implemented, violated or resisted and what this implies for daily juvenile justice practices and experience. 
Secondly, in the context of juvenile justice, children's rights also were criticised in Europe for being a possible motor of "punitiveness" (Snacken \& Dumortier, 2012). Even though children's and human rights are claimed to function as a bulwark against punitive tendencies (such as harsh disproportionate punishments) the opposite can be true as well (Dumortier et al., 2012). Indeed, advocating procedural safeguards for children, begs the question, why children should not then be sent to the adult penal system with all procedural safeguards at its disposal? In the United States, the trend towards a justice model for juveniles was easily transformed into a plea to send more and more children to the adult penal system with, as a consequence, more punitive measures at its end (Cavadino \& Dignan, 2006). In European countries, children's procedural rights were used to render juvenile justice more just, but at the same time more punitive towards young delinquents. With this in mind, children's procedural rights can be compared to a Trojan horse: the price for a stronger legal position during juvenile justice proceedings is a harsher punishment at the end of the ride (Dumortier, 2012).

Finally, the UN CRC was also criticised for legitimating and upholding a separate (juvenile) approach vis-à-vis children who remain to be identified as 'not yet', as people in need of care... and in need of adults (Cordero Arce, 2012). This childhood image of the $\mathrm{UN} \mathrm{CRC}$ is in line with the developmental criminology perspective that, from the end of the 80 's, claimed that a child should be considered differently from an adult, requiring a specialised form of justice (Fernández Molina 2015, 616). It is exactly this perspective that legitimises the UN CRC claims that children should be accorded the same due process rights as adults, but that they must not be treated the same way as them. However, this dichotomy between adults and those identified as "not yet" adults in turn legitimises that children do not receive the same fundamental human rights as adults and could thus be seen as being "discriminated". In this way, the UN CRC merely accords to children "the right to participate' instead of 'children's citizenship' (Cordero Arce, 2015b), the latter implying at the least political influence and norm making capacity. The UN CRC, being "a gift" of adults that was "drafted for children, without children", lacks legitimacy vis-àvis children (Cordere Arce, 2015b, 297). According to Cordero Arce this implies that "paternalism" and the idea that children are "not yet" ready to deal with (certain) "adult rights", still lies at the heart of the UN CRC (Cordero Arce, 2015b, 297-298). From a historical long-term perspective, Cordero Arce's argumentation raises the question of whether the UN CRC should be seen as a clear fracture in juvenile justice history. Or are the central concepts of the UN CRC concerning juvenile justice, such as 'the best interest of the child' and the need for a 'separate' child adapted approach above all else in line with and in continuity of classic child protection discourses and practices?

\section{From children's rights in Europe to procedural justice}

In this third section, we maintain that a procedural justice perspective can help scholars to rethink (research on) juvenile justice and children's rights in Europe. Prior to discussing why and how this perspective can be helpful - in the next section - we will first explain what this perspective implies and why a procedural justice perspective is also important for juvenile justice. 


\section{On procedural justice}

In general, the idea of procedural justice draws attention to the fact that the attitude and the treatment of people by institutions in general, and the judicial institutions in particular, can influence their image of justice, encourage their consideration as legitimate or illegitimate and as a consequence stimulate more or less spontaneous obedience to judicial decisions (Tyler, 2000, 120). More precisely, Fagan and Tyler $(2005,220)$ emphasise that the analyses of procedural justice are built on these premises: a) 'people have certain opinions about the legitimacy of the authorities'; b) 'these views define their behaviour'; c) 'those views arise from social interactions and experiences with institutions'. It is assumed that people speaking about justice and legitimation of institutions care about final decisions, in addition to caring about the processes of making decisions and about the treatment received from authorities.

If that is so, it is essential to question which elements people will consider when evaluating a treatment as fair. Leventhal (in Tyler 1988, 104-105), points to seven criteria of procedural justice provided by the institutions: consistency and equal treatment for people in similar situations; ability to eliminate bias or the impact of external factors on the decision itself; security and predictability in decisions; the possibility of appealing decisions considered unfair; the possibility that parties have the opportunity to participate in decision-making; decisions are made in accordance with general standards of justice and morality.

Others, such as Bottoms and Tankebe $(2012,145)$ in the United Kingdom claim that the concept of procedural justice implies two distinct, although complementary, issues. First, they refer to the 'quality in decision-making', which has to do with the respect for principles and procedural safeguards recognised by national and international laws including, among others, the recognition and implementation of the right to be heard in decisions that affect them, the independence and impartiality of the decision maker, the motivation of decisions or consistent decisions in similar cases. On the other hand, they consider that procedural justice pertains to the 'quality of treatment' - which is to be treated with dignity or respect. It is interesting to note that the legitimacy of an institution will vary depending on whether one or both dimensions of procedural justice are considered and respected. Sometimes, focusing solely on the quality of decision-making and being careless with the quality of treatment can create the idea that the protection of rights is superficial, because it disrespects people.

There are indeed two main and complementary reasons for paying attention to this kind of justice. First of all, procedural justice and its attempt to improve institutional legitimacy acknowledges the experiences of people who come into contact with judicial institutions. Procedural justice aims to foster a feeling of justice and, in consequence, to achieve greater conformity and obedience to the rules and institutional decisions. Thus, the pragmatic aspect of procedural justice points to the idea that 'people are more likely to accept the decisions of the legal authorities and support the legal system when their experience of the legal process is fair and respectful' (Woolard et al., 2008, 208). Nonetheless, the idea of procedural justice is also incumbent on authorities and institutions themselves because they are aware (or should be) that power cannot be maintained if a majority of the population does not consider them as legitimate and does not obey 
their decisions spontaneously. Thus, theories about power and state emphasise that it is important to care about the reasons why an authority and its decisions are obeyed. That is why in democratic governments the idea of policing by consent (or by conviction) imposes on the one of government by force.

\section{The need for procedural justice in juvenile justice}

Even though the premises of procedural justice are very interesting, it remains necessary to examine whether these premises can and should be extended to institutions working with children, and in particular, the juvenile justice system. The doubts about the limits and possibilities of procedural justice in children's institutions are justified when taking into account the public of juvenile justice: children with a presumed cognitive immaturity and limited ability to understand all dimensions of the crime committed and the reasons and consequences of the measures imposed on them by juvenile judges.

However, following Woolard and others, exploiting the potential of procedural justice might be very revealing in the area of juvenile justice $(2008,209)$. Woolard and colleagues consider that precisely at the time of transition from childhood to adulthood, the child increases his or her expectations to be treated 'as an adult'. They assume that young people, 'increasingly expect to have a voice in decisions that affect their lives and to be treated with dignity and respect. Combined with immature psychosocial capacities that contribute to a foreshortened time perspective and a reduced ability to take others' perspectives into account, adolescents may have a heightened attention to fairness in justice system procedures' (Woolard et al., 2008, 209) and interpersonal relationships. In addition, Piquero highlights that the idea of procedural justice during adolescence is especially interesting because 'this is the development period during which individuals are beginning an adult-like understanding of society and its institutions and when they venture outside the closed systems of family and school to experience laws and rules in a variety of social contexts where rule enforcement is more integrated with the adult world' (Piquero et al., 2005, 268).

Some authors agree that compliance with the law and understanding of court decisions depend on the cognitive maturation process of the child and on their psychosocial development. In that sense, Fagan and Tyler $(2005,219)$ consider that 'the child develops an orientation to the law and legal authorities early in his life, and that early orientation shapes the behaviour of both adolescents and adults.' They ensure that children, when ageing, will increase their contact with adult rules and institutions and precisely that experience can shape children's notions concerning the law and legal actors.

Apart from psychosocial reasons, we can also think of pedagogical reasons for promoting the premises of procedural justice in the field of juvenile justice. Even if it seems obvious, decisions imposed by the juvenile judge should be supported by parents and children to increase their educational impact. Pedagogical theories and practices insist on the fact that measures imposed on children without their adherence is 'anti-pedagogical'. Without adherence, the judicial measure can be accomplished, but the effects will not be lasting, nor will this achieve any accountability for the child. Furthermore, the Recommendation (2008) 11 of the Committee of Ministers to member states on the 
European Rules for juvenile offenders subject to sanctions or measures highlights 'the obligation of any competent authority to seek possible cooperation with juvenile offenders and their parents or legal guardians' (25.b).

Finally, there are also legal reasons to promote the premises of procedural justice within the field of juvenile justice. As indicated, since 1989, the UN CRC proclaims that children should be treated as subjects with rights who pursue their own interests and who have their own voice. According to article 12 of the UN CRC, children have the right to participate and be involved in processes of decision making, expressing their views freely in all matters that affect them and they shall be provided the opportunity to be heard in any judicial proceedings affecting them.

Taking into account the importance of a procedural justice perspective, also for juvenile justice, we will discuss in the next section how this perspective can help us to rethink children's rights in a way that can increase juvenile justice's legitimacy.

\section{How can procedural justice help us to rethink children's rights and juvenile justice in Europe?}

In the remainder of this article, we will elaborate on four important implications of a 'procedural justice' perspective on children's rights and juvenile justice in Europe. More specifically we will elaborate on the fact that procedural justice and its idea of caring about "just" processes 1) insists on the implementation of the rights and to take children's rights seriously; 2) upholds a 'double perspective' on legitimacy where both powerholders (the professionals) and citizens (the children) are deemed important; 3) strongly focuses on the need and interest for children to 'participate' in the judicial process; and finally, 4) acknowledges that age does matter in the 'development' of feelings and perceptions of legitimate justice, implying that legitimation of (juvenile) justice can suffer if this 'agefactor' is neglected.

\section{The need to take children ('s rights) seriously}

It is important to remember that procedural justice insists on the idea that a decision is perceived as fair when the decision-making process is considered fair. This concept has several implications to rethink and "to take children's rights seriously" (Freeman, 198788 ; 2007). First of all, it implies that rights should be considered as means to achieve certain ends, not merely ends in themselves. So, if human rights in general are perceived as barometers of justice, we can claim that the implementation of the rights and the realisation of their objectives will be the best and most trustworthy barometer of justice. Furthermore, not only does it matter whether (or not) rights have been implemented, but the central question should be how they have been implemented and experienced. Do children's rights achieve their goals (such as enhancing the child's participation) and do they actually meet the child's needs (such as the need to be heard)?

Secondly, we can consider rights and their implementation as a form of communication between authorities and citizens. Bottoms and Tankebe $(2013,67)$ mention that to increase authority's legitimation and citizen's consideration, this communication should consist of 
a rational dialogue and not an angry or disrespectful one or an unequal discussion. In the same way, children's rights can be implemented in a respectful but also in a way that makes the child feel bad or angry. Christiaens and Françoise (2015) for example mention how youngsters in Belgium, after being heard by the juvenile judge, feel disappointed and or angry because the judge's decision was already taken before they were heard. That is exactly why, as noted by General Comments $\mathrm{n}^{\circ} 5$ and 10 , professionals should be 'voiced, informed and trained' not only on laws, but also on special needs for children (Hammarberg $2008,195)$. In this sense, juvenile justice's legitimacy depends heavily on the real implementation and the child's experiences of the rights and not their mere existence in national and international law.

Moreover, rights can also be seen as social as well as political decisions and children should intervene in social and political processes, in the definition, in addition to the positivization of their rights. 'Rights, then function as a starting point for dialogue' (Vanobbergen, 2015, 73) and we can assume then that rights will be perceived as fairer by the children if, in the processes of defining them, children were also allowed to intervene. Even though children usually are excluded from the processes of positivization of rights, experts in juvenile justice and politicians should take into account (research on) children's voices and perceptions (Cordero Arce, 2015, 286-297) to modernise laws and improve children's rights implementation. Desmet and others $(2015,418,424)$ consider that 'rights should not be considered as individual entitlements but rather as an interpersonal or interrelational practice' and as an 'interactive process between all involved'. To reach this objective, the first aim would be to provide children with enough autonomy and agency to enable them to define those rights and give meaning to their lives. However, this autonomy seems only possible through the real and full implementation of all (children's) rights: the social, political and civil. Indeed, Verhellen $(2015,55)$ already noted that, 'the more their competencies are recognised and realised, the more the children will gain a prominent space and place in society, and the more they will ultimately be able to challenge the dominant child image that still does not see them as capable human beings on their own.'

\section{The need for a double perspective}

Procedural justice claims that to be perceived as legitimate, the perspectives and lived experiences of (at least) two important players must be taken into account: the powerholders and the citizens. In the case of juvenile justice that would be the perspectives and experiences of both the children who come into conflict with the law as well as the juvenile justice professionals.

In a classical legal perspective, juvenile justice's institutions and professionals will gain legitimacy, first, by adhering to an international body of standards. This adherence will then be followed by a process of adapting the national legal framework to these international standards. Finally, an adaptation of processes or a creation of institutions and structures to reach the agreed international objectives on the implementation of the rights (rights monitoring) will further strengthen juvenile justice's legitimacy. Meanwhile, it seems that juvenile justice's professionals and policymakers reflect much less on how 
professionals experience rights and what are their actual views on children's rights. Indeed, such a 'procedural justice' perspective would require a discussion on the meaning and the goals of children's rights, in addition to an evaluation of practices developed along with children's rights and their impact on professionals. If, for example, professionals resist children's rights it is important to understand and contextualise their resistance. Without such understanding, the implementation of children's rights is at risk of encountering the same kind of problems over and over again. At the same time, this perspective implies improved training for professionals who are involved in the work of 'implementing' children's rights. They should be sensibilised to the idea that children's rights contribute to the legal socialisation of children, to the legitimation of juvenile justice institutions and even regarding compliance with their decisions. Moreover, professionals have to learn how to deal with children's voices and opinions, taking into account that this is not an intuitive practice (Liefaard \& Rap, 2016).

However, to enhance the legitimacy of juvenile justice, not only should professionals be voiced, informed and trained, the same goes for the children in conflict with the law. As mentioned above, if rights are considered 'interrelational', (Desmet et al., 2015) then children's opinions concerning the implementation of 'their' rights and fairness of the system matter. Moreover, giving children a voice can be seen as an important step in this emancipatory process. After all, today, it remains unclear when children perceive justice institutions and professionals as fair (or not). Maybe children value as fair an adult explaining, in an adapted manner, their basic rights and their implications - that they can participate, have a voice in the decision-making process that directly relates to their life, and or that they are treated with dignity and respect. But maybe children specifically value the 'deal' or 'the outcome' at the end of the process and perceive justice as fair when the outcome is fair notwithstanding their level of participation or correctness. This brings us to a third, and quite ambiguous as well as complex issue of children's rights: the right of the child to participate.

\section{Participation: what does it mean?}

A third core issue in 'procedural justice' is the idea of citizen's participation because when they participate in the decision-making process, they will have a higher impression of fairness. Kilkelly $(2008,41)$ remarks that "according to the Committee on the Rights of the Child, alleging that the child is criminally responsible implies that he/she is 'competent and able to effectively participate in the decisions' made about infringements of the criminal law". Following this train of thought Krappmann $(2010,502)$ notes that ' $(t)$ he notion of participation captures an essential feature of the convention. The convention highlights that the child is a human being, who has the right to be respected as a unique individual with an own perspective and personal intentions by fellow human beings and also by the state, its institutions and other organisations.' Indeed, following a procedural justice perspective, a decision from juvenile justice's authorities will be perceived as fair by children when and if they had the possibility to participate. That is why participation rights are also those most strongly emphasised by the UN CRC and the European standards. Mainly the Directive (EU) 2016/800, on procedural safeguards for children who are suspects or accused persons 
in criminal proceedings and the Guidelines of the Committee of Ministers of the Council of Europe on child-friendly justice ask for an adaptation of juvenile justice to children's needs rendering their effective participation in the process possible.

However, the exact meaning of "participating rights" of children needs further reflections ${ }^{4}$. First of all, the discussion concerns penal practices in the context of a repressive apparatus where obedience is expected and 'punishments' or 'sanctions' are distributed, not discussed. Participating in this 'repressive game' is not easy for adults, let alone for adolescents or young children. Moreover, the professionals involved are 'repeat players' who know how to 'play the game', while the children and youths are, most of the time, inexperienced 'one-shotters' (Galanter, 1974). In this context, participation can only be understood as a way of following the rules of a game already established by adults. As a consequence, in practice, children's participation becomes limited to a means of attaining the truth (Bosisio, 2012, 153), or as a moral dialogue between the judge and the child (Weijers, 2002, 146-147).

Secondly, we are facing a child with known cognitive immaturity, lesser psychosocial development and with few(er) experiences in life as well as with human relationships than adults. As a consequence, the child is more vulnerable and at the same time more dependent on adult opinions concerning correctness or fairness (Peterson-Badali, Abramovitch \& Duda, 1997) ${ }^{5}$. It is exactly because of this double vulnerability that the UN CRC proclaims several protection rights for the child and imposes positive duties on the member states to 'protect' children. However, this idea of protecting children enhances an "adult culture" where children are expected to listen to adults. In this same sense, 'adult structures were not developed with children and young people's participation in mind' (Tisdall, 2015, 192). Moreover, adults decide how and when children's opinions should be considered (Krappmann, 2010, 508). Besides, this protectionist perspective seems to be built on the idea that participation implies making choices but also taking or bearing responsibilities for those choices (even if they turn out damaging for the child). As a consequence, it remains unclear how to reconcile this idea of child participation with the positive duty of the state and adults to protect children. How to avoid participation from becoming "a spurious, paternalistic and oxymoronic protected participation" (Cordero Arce, 2015b, 292 , original italic)?

Here we enter a third fundamental problem, which concerns when children have the right to participate. From what age do children really have the competence to participate in a judicial process? Steinberg (2000) considers that children from the age of fourteen years old have their cognitive competence quite developed, but the psychosocial development still has a long way to go. According to Grisso and Schwartz (2000) several issues concerning the psychosocial development of the child should be taken into account when assessing the child's competence to participate. For example, the process of participation requires attention to understand what the police are saying in a moment of tension, the rational ability to make decisions throughout the process and weigh the consequences of these decisions, or self-control to behave in the courtroom (in Fernández Molina 2015, 627-629).

Finally, a fourth fundamental question deals with the outcomes of the child's participation. According to article 12 of the UN CRC "due weight" has to been given to the child's opinions, views and wishes. But who decides and on the basis of what criteria whether or 
not due weight has been given? Moreover, research in the United States and in Europe reveals that letting the child participate can also be used against the child. For example, in the United States, children and youth, like adults, have the right to waive legal counsel during police interrogations, and they largely use this right. That is exactly why Feld suggests that under the age of 16 years the presence of a lawyer during police interrogations should be compulsory (Feld, 2012). Or, in Spain, the fact of accepting a process of reparation implies the assumption of culpability. Hence, the right to participate can well act as a convenient 'legitimator' of the juvenile justice system and its professionals without actually strengthening the position of children nor empowering them.

On top of this, it seems as though participation rights of children are always accompanied with the duty to bear (criminal) responsibilities and consequences (just as is the case with adults). That is why we should remember that claiming full autonomy or "citizenship" (Cordero Arce, 2015b) to the child can be, specifically in the field of juvenile justice, a real turbo for punitive tendencies and 'harsh' justice. It is exactly this kind of reasoning that pleads in favour of transferring young people to the adult criminal system. Here we enter the fourth key concept within the procedural justice perspective: age does and must matter.

\section{Age matters but in what manner?}

According to 'procedural justice' literature, children and young people 'develop' an orientation to the law and a sense of fairness (or unfairness) for justice from their early childhood onwards. These childhood, but also adolescent experiences, are of the utmost importance for young adults' perception on the legitimacy (or non-legitimacy) of justice. In other words, people 'develop' their perspective on justice based on their own experiences and hearsay. That is exactly why any justice system that deals with children, adolescents and young people should be extremely cautious in their approach. Article 40.1 UN CRC remembers that children should be "treated in a manner consistent with the promotion of the child's sense of dignity and worth, which reinforces the child's respect for the human rights and fundamental freedoms of others and which takes into account the child's age and the desirability of promoting the child's reintegration and the child's assuming a constructive role in society". Experiencing at a young age very unfair system may have a negative impact on adulthood perceptions of the (non) legitimacy of justice. Juvenile justice should keep in mind this idea of being fair along the whole process of making decisions.

At the same time, taking into account this 'developmental' perspective, the UN CRC finds arguments to defend a child specific juvenile justice system. This right to a child specific justice system is grounded on the right of children to be treated in a just and respectful way according to their needs. As contrasted with Cordero, one can wonder whether a child specific system is 'by definition' grounded or cannot be grounded on anything other than on (remnants of) paternalism and on discriminatory grounds. On the contrary, to our opinion, a child specific justice system can and should be grounded on the age-factor and on the fact that treating children as adults will be, in practice, discriminating for children. After all, children do not have equivocal developmental skills and life 
experiences as adults and, as a consequence, encounter more difficulties to cope with an inevitably harsh, repressive system. If adults already have difficulties 'to fight' and 'resist' the criminal justice system, how can we expect children to do the same (Naffine, 1992, 94)?

Indeed, research reveals how children and youngsters are even more at risk of giving false confessions during police interrogations (Feld, 2012), of being victimised during periods of imprisonment (Goldson \& Kilkelly, 2013, 346) and of having longer criminal trajectories when being transferred out of the juvenile justice system into the adult system (Nuytiens, Jaspers \& Christiaens, 2015). Treating children just as adults might be defendable from a purely judicial-philosophical point of view (the principle of equality). However, from a procedural justice perspective, not taking into account the defendant's age will, in practice, discriminate the younger defendants and decrease their feeling of justice. Hence, if we want children, just as adults, to enjoy their rights and to experience a system where they are treated with dignity and respect, we need to adapt judicial processes and we need to take into account the defendant's age. In other words, to achieve equality and procedural justice for all, taking into account the citizen's age is a bare necessity.

The "developmental framework" constructed during the last decade by the American Supreme Court might turn out very inspiring for further research on this question in Europe, even though the empirical basis for this framework, such as "brain science", definitely needs further reflections ${ }^{6}$. Nevertheless and according to Scott, Grisso, Levick and Steinberg (2016), there are three key themes that legitimate why "children are different" for purposes of criminal punishment and that form the "developmental framework" of the American Supreme Court: 1) children are less culpable than adults, 2) they have a greater potential for reform and 3) they are less able to navigate the justice process.

\section{Conclusion and discussion: scientific challenges}

Twenty-five years after the introduction of the UN CRC, children's rights in European juvenile justice remain a difficult burden to bear in daily practice. Even though numerous reasons have been advanced to explain this non-achievement, this contribution suggests another way to rethink and rework children's rights. Our departure point has been a procedural justice perspective and the idea that the decision-making processes matter when experiencing justice. This perspective reminds us that procedural rights and child participation in juvenile justice are important for legal socialisation, accountability, and for children's sense of justice. Moreover, if children experience juvenile justice institutions as legitimate, they will probably obey, in a more spontaneously fashion, their instructions and decisions.

However, before re-theoritising children's rights, empirical insights on how children's rights are implemented and experienced in daily practice are of the utmost importance. The research question hereby is not just whether children's rights are implemented (or not) in daily juvenile justice practice, but primarily on how they affect or shape juvenile justice practices and how they are experienced by both children in conflict with the law and the professionals involved. We need to unravel the children's rights in action and the experiences of children's rights by those directly involved (children and professionals) in order to understand how children's rights actually work and how they condition children's feelings of 
justice. Only then can we continue to rethink and re-theoritise juvenile justice and children's rights. Specifically, the meaning of child participation in a repressive-educational context that, moreover, is led and structured by adults is in need of further clarifications.

From a developmental, pedagogical and judicial perspective, it is clear that age plays an important role in the possibilities of participating in judicial processes. However, the impact of age on citizens' participation capacities, but also on their abilities to enjoy and bear "citizenship" needs further investigation. Taking into account the less mature and experienced status of children and youths, it seems clear that these research methods will have to discover a method to account for the age-factor and the implications (also for scientists) of working with children and letting them participate in an effective as well as autonomous manner. In this sense, scientific research itself will and must become more empowering and emancipatory for children and youngsters themselves. Also, in regard to the professionals involved, the question raises what role scientific research can and should play in the formation of professionals themselves.

Even though we argue that a procedural justice perspective will be very revealing in the area of (legitimate) juvenile justice and children's rights, we must be aware of its limits and potential pitfalls. Our interest for 'procedural justice' should not set aside the necessary realisation of 'social justice' through social and economic rights. Mainly because rights are indivisible in the sense that one set of rights cannot be realised without the implementation of the others. All rights work in favour of our 'human dignity' and equality. In practice, however, there are numerous signals suggesting that the social and economic rights of children in conflict with the law are quite problematic in most western juvenile justice systems. Classical criminological research claims that juvenile delinquency is (also) a consequence of their societal vulnerability, their being 'at (social) risk'. Even when juvenile justice in Europe works in a procedural and just manner, it still can be (viewed as) not legitimate, namely when it predominantly targets "the usual suspects" who already benefit the least from their socio and economic rights in the European welfare state. As a consequence, scientific research on children's rights and procedural justice in Europe should also try to clarify this link between procedural (in)justice and social (in) justice vis-à-vis youngsters.

In closing, after 25 years of children's rights in Europe, researching practices and experiences with children's rights in juvenile justice should set the research agenda on children's rights for the near future. Ultimately this will increase our knowledge on why children obey the law and why and how we can take children('s rights) seriously.

\section{Funding}

The author(s) received no financial support for the research, authorship, and/or publication of this article.

\section{Notes}

1. See Liefaard (2016, 909-910) considering this (and others) decisions of the European Court of Human Rights as an antecedent of child-friendly justice.

2. For example, see in the International Handbook of Juvenile Justice (Decker \& Marteache, 2017) the different chapters on European countries and their, "stance towards the UN Committee on the Rights of the Child". 
3. With some large-scale research on the rights of the children to be heard in Europe (Rap \& Weijer, 2014) and more small-scale European research on children's rights during police interrogations of young suspects (Vanderhallen a.o., 2016). Also, national research such as the right of the child to be heard in daily (Belgian) juvenile court's practices (Françoise \& Christiaens, 2015). See, for comparative review on how the principles of UN CRC have been incorporated to national laws, the research of Lundy, Kilkelly and Byrne (2013). On the impact of UN CRC on the measure of imprisonment of children (Goldson and Kilkelly (2013).

4. According to Lundy (2007) for example the phrases which are commonly used as abbreviations for Article 12 of the UN CRC, such as 'pupil voice', but also 'participation' or 'consultation' of the child have the potential to diminish its impact. She proposes a new model with four key elements for conceptualising Article 12 - Space, Voice, Audience and Influence.

5. In that sense, Liefaard $(2016,926)$ points out that because of emotional and cognitive development of children, "a relatively low minority age of criminal responsibility poses serious challenges to children's participation in court". He says that the age "has implications for the way children are treated in the different stages of the juvenile justice system, which also affects the way parents are involved, the age at wich children should (or should not) be deprived of their liberty and the way children are informed about the proceedings" (Liefaard 2015, 241).

6. On the developmental approach of the US Supreme Court and the references to scientific evidence of human brain maturation, see Cohen, Bonnie, Taylor-Thompson and others (2016). On some potentialities but also some pitfalls of such a developmental approach, see Buss (2016).

\section{References}

Bosisio R (2012) Children's Right to be Heard: What Children Think. International Journal of Children's Rights 20: 141-154.

Bottoms A and Tankebe J (2013) 'A voice within': power-holders' perspectives on authority and legitimacy. In: Tankebe J and Liebling A (eds.), Legitimacy and Criminal Justice, pp. 60-82. Oxford: Oxford University Press.

Bottoms A and Tankebe J (2012) Beyond procedural justice: a dialogic approach to legitimacy in criminal justice. The Journal of Criminal Law and Criminology 102(1): 119-170.

Buss E (2016) Developmental jurisprudence. Temple Law review 88: 741-768.

Cavadino M and Dignan J (2006) Penal systems: A comparative approach. London Thousand Oaks and New Delhi: SAGE Publications.

Cauffman E and Steinberg L (2000) (Im)maturity of judgement in adolescence: why adolescents may be less culpable than adults. Behavioural Sciences and the Law 18: 741-760.

Christiaens J (Ed) (2015) It's for your own good. Researching youth justice practices. Brussels: VUB Press.

Christiaens J and Nuytiens A (2009) Transfer of juvenile offenders to adult court in Belgium: critical reflections on the reform of a moderate practice. Youth Justice 9 (2): 131-142.

Cohen O, Bonnie R, Taylor-Thompson K and Casey B (2016) When does a juvenile become adult? Implications for law and policy. Temple Law Review 88: 769-788.

Cordero Arce M (2015) Hacia un discurso emancipador de los derechos de las niñas y los niño. Lima: Ifejant.

Cordero Arce M (2015b) Maturing Children's Rights Theory. From Children, With Children, Of Children. International Journal of Children's Rights 23 (2): 283-331.

Cordero Arce M (2012) Towards an Emancipatory Discourse of Children's Rights. International Journal of Children's Rights 20: 365-421.

de Graaf E, Christiaens J and Dumortier E (2017) Children behind Belgian Bars: Rights and Resistance against the Pains of Imprisonment. In: Liefaard T and Sloth-Nielsen J (Eds.) The United Nations Convention on the Rights of the Child: Taking Stock after 25 Years and Looking Ahead, pp. 611-633. Leiden: Brill| Nijhoff.

Desmet E, Lembrechts S, Reynaert D and Vanderhole W (2015) Conclusions. Towards a field of critical children's rights studies. In: Vanderhole W et al. (eds.) Routledge International Handbook of Children's Rights Studies, pp. 412-429. London: Routledge.

Donzelot J (1979) The policing of families. Maryland/London: The Johns Hopkins University Press.

Dumortier E, Snacken S, Gutwirth S and De Hert P (2012) The rise of the penal state. What can human rights do about it? In: Snacken S and Dumortier E (eds.) Resisting punitiveness in Europe? Welfare, Human Rights \& Democracy, pp. 107-132. New York: Routledge. 
Dumortier E (2012) Kinderrechten tegen punitiviteit? Over de perverse wending van het kinderrechtenvertoog (Children's rights against punitiveness? On the perverse turn of the children's rights discourse), Tijdschrift voor Jeugdrecht en Kinderrechten 13: 228-238.

EU Directive (2016) /800 of the European Parliament and of the Council of 11 May 2016 on Procedural safeguards for children who are suspects or accused persons in criminal proceedings.

European Court of Human Rights (1988) Bouamar v. Belgium, Date: 29 February 1988. European Court of Human Rights (1999) T and Vv. United Kingdom. Date: 16 December 1999.

Fagan J and Tyler T (2005) Legal socialisation of children and adolescents. Social Justice Research 18(3): 217-242.

Fass P (Ed) (2013) The Routledge History of Childhood in the Western World. New York: Routledge.

Feld B (2012) Kids, cops and confessions. Inside the interrogation room. New York: University Press.

Fernández Molina E (2015) Repensando la justicia de menores. In: Miro F, Agustina JR, Medina JF and Summers L (Ed) Crimen, Oportunidad y vida diaria. Libro Homenaje al prof. Marcus Felson, pp. 613-647. Madrid: Dykinson.

Françoise C and Christiaens J (2015) Appearing in Court and the Hearing of Minors: Practices of Judges of the Juvenile Courts in Belgium. In: Christiaens J (Ed) It's for your own good. Researching youth justice practices. Brussels: VUB Press.

Freeman M (1987-88) Taking children's rights seriously. Children \& Society 4: 299-319.

Freeman M (1997) The Moral Status of Children. Essays on the Rights of the Child. Nijhoff: Brill.

Freeman M (2007) Why it remains important to take children's rights seriously. The International Journal of Children's Rights 15 (1): 5-23.

Galanter M (1974) Why the "haves" come out ahead: speculations on the limits of legal change. Law and Society Review 9(1): 95-160.

General Comment (2007) $\mathrm{n}^{\circ} 10$ of the United Nations Children's Rights Committee on Children's rights in juvenile justice.

General Comment (2009) n ${ }^{\circ} 12$ of the United Nations Children's Rights Committee on The right of the child to be heard.

Goldson B and Muncie J (2015) Children's human rights and youth justice with integrity. In: Goldson B and Muncie J (eds) Youth Crime and Justice $2^{\text {nd }}$ edition. pp. 227-257. Los Angeles/London: SAGE publications.

Goldson B and Kilkelly U (2013) International human rights standards and child imprisonment: potentialities and limitations. International Journal of Children's Rights 21: 345-371.

Goodwin De Faria Ch and Marinos V (2012) Youth understanding and assertion of legal rights: examining the role of age and power. International Journal of Children's Rights 20(3): 343-364.

Grisso T, Steinberg L, Woolard J, Cauffman E, Scott E, Graham S and Schwartz R (2003) Juveniles' competence to stand trial: A comparison of adolescents' and adults' as trial defendants. Law and Human Behaviour 27(4): 333-366.

Hammarberg Th (2008) A Juvenile Justice Approach Built on Human Rights Principles. Youth Justice 8(3): 193-196.

Junger-Tas J and Decker S (eds.) (2006) The International Handbook of Juvenile Justice. Dordrecht : Springer.

Kilkelly U (2008) Youth Courts and Children's Rights: The Irish Experience. Youth Justice 8(1): 39-56.

Kilkelly U and Lundy L (2006) Children's rights in action: using the UN Convention on the Rights of the Child as an auditing tool. Child and Family Law Quaterly 1(3): 331-350.

Krappmann L (2010) The weight of the child's view (article 12 of the Convention on the Rights of the Child). International Journal of Children's Rights 18: 501-513.

Liefaard T (2016) Child-friendly justice: protection and participation of children in the justice system. Temple Law Review 88: 905-927.

Liefaard T (2015) Juvenile justice from an international children's rights perspective. In: Vanderhole W, Desmet E, Reynaert D and Lembrechts S (eds.) The Routledge International Handbook of Children's Rights, pp. 234-256. Oxford: Routledge. 
Liefaard T and Rap S (2016) Can anyone hear me? Participation of children in juvenile justice. A manual on how to make European juvenile justice systems child-friendly. Brussels: IJJO.

Liefaard T and Sloth-Nielsen J (Eds.) (2017) The United Nations Convention on the Rights of the Child: Taking Stock after 25 Years and Looking Ahead. Leiden: Brill| Nijhoff.

Lundy L (2007) 'Voice' is not enough: conceptualising Article 12 of the United Nations Convention on the Rights of the Child. British Educational Research Journal 33 (6): 927-942.

Lundy L, Kilkelly U, Byrne B and Kang J (2012) The UN Convention on the Rights of the Child: a study of legal implementation in 12 countries. Belfast: Queen's University (qub.ac.uk/research-centres/CentreforChildrensRights, consulted on July $17^{\text {th }} 2017$ ).

Lundy L, Kilkelly U and Byrne B (2013) Incorporation of the United Nations Convention on the Rights of the Child in Law: A comparative Review. International Journal of Children's Rights 21: 442-463.

Muncie J (2009) The United Nations, children's rights and juvenile justice. In: Taylor W, Earle R and Hester R (eds.) Youth Justice Handbook: Theory, policy and practice, pp. 20-21. Cullompton: Willan.

Naffine N (1992) Children in the children's court: can there be rights without a remedy. International Journal of Law and the Family 6: 76-97.

Nuytiens A, Jaspers Y and Christiaens J (2015) Trajecten van uithanden gegeven jongeren in de volwassenheid (Pathways of transferred offenders into adulthood) Panopticon 36 (3): 248-265.

Peterson-Badali M, Abramovitch R and Duda J (1997) Young children's legal knowledge and reasoning ability. Canadian Journal of Criminology 39(2): 145-170.

Piquero A, Fagan J, Mulvey E, Steinberg L and Odgers C (2005) Developmental trajectories of legal socialisation among serious adolescent offenders. Journal of Criminal Law and Criminology 96(1): 267-298.

Platt A (1977) The Child Savers: the Invention of Delinquency. Chicago: University of Chicago press.

Rap S and Weijers I (2014) The effective youth court. Juvenile justice procedures in Europe. The Hague: Eleven International Publishing.

Recommendation (2008)11 of the Committee of Ministers to member states on the European Rules for juvenile offenders subject to sanctions or measures.

Rush P (2002) The government of a generation: the subject of juvenile delinquency. In: Muncie J, Hughes G and McLaughlin E (Eds.) Youth Justice. Critical Readings, pp. 138-158. London: SAGE. This chapter is taken from The Liverpool Law Review, Vol. 14, No. 1, 1992, pp. 3-41 (abridged).

Scott E, Grisso T, Levick M and Steinberg L (2016) Juvenile sentencing reform in a constitutional framework. Temple Law Review 88: 675-716.

Snacken S and Dumortier E (2012) Resisting punitiveness in Europe? Welfare, human rights and democracy. New York: Routledge.

Supreme Court (1966) Kent v. United States $\left(\mathrm{n}^{\circ} 104\right) 383$ U.S. 541.

Supreme Court (1967) Gault v. United States (n 116) 387 U.S. 1.

Tisdall E and Kay M (2015) Children and young people's participation. A critical consideration of article 12. In: Vanderhole W et al. (eds.) Routledge International Handbook of Children's Rights Studies, pp. 185-200. London: Routledge.

Tyler T (2006) Psychological perspectives on legitimacy and legitimation. Annual Review of Psychology 57: 375-400.

Tyler T (2000) Social Justice: outcome and procedure. International Journal of Psychology 35 (2): 117-125.

Tyler T (1988) What is procedural justice? criteria used by citizens to assess the fairness of legal procedures. Law and Society Review 22(1): 103-135.

Van de Kerchove M (1977) Des mesures répressives aux mesures de sûreté et de protection. Réflexions sur le pouvoir mystificateur du langage. Revue de droit pénal et de criminologie: 245-279.

Vanderhallen M, Van Oosterhout M, Panzalvota M and de Vocht D (2016) Interrogating Young Suspects: Procedural Safeguards from an Empirical Perspective. Antwerpen: Intersentia.

Vanobbergen B (2015) Children's rights and childhood studies. From living apart together towards a happy marriage. In: Vanderhole W et al. (eds.) Routledge International Handbook of Children's Rights Studies, pp. 60-76. London: Routledge.

Veerman P (1992) The rights of the child and the changing image of childhood. Dordrecht/Boston/London: Martinus Nijhoff Publishers. 
Verhellen E (2000) The convention on the rights of the child: background, motivation, strategies, main themes. Leuven: Garant.

Verhellen E (2015) The Convention on the Rights of the Child. Reflections from a historical, social policy and educational perspective. In: Vanderhole W et al. (eds.) Routledge International Handbook of Children's Rights Studies, pp. 43-59. London: Routledge.

Weijers I (2002) The Moral Dialogue: A Pedagogical Perspective on Juvenile Justice. In: Weijers I and Duff A. Punishing Juveniles. Principle and Critique, pp. 135-154. Oxford: Hart Publishing.

Woolard J, Harvell S and Graham S (2008) Anticipatory injustice among adolescents: age and racial/ethnic differences in perceived unfairness of the justice system. Behavioural Sciences and The Law 26: $207-226$.

\section{Author biographies}

María José Bernuz Beneitez obtained her Ph. D. in Law at the University of Zaragoza (Spain) with a doctoral thesis on juvenile justice transformation in Spain. She is a University Lecturer at the department of Philosophy of Law and researcher at the Laboratory of Sociology of Law at the University of Zaragoza. Her research mainly focuses on juvenile justice systems, children's rights in practice, procedural justice and social justice, restorative justice.

Els Dumortier $\left({ }^{\circ} 1972\right)$ holds a master's degree in law and in criminology and she obtained her Ph. D. in Criminology at the Vrije Universiteit Brussel. Today, she is full time professor in "youth law" and "youth criminology" at the Faculty of Law and Criminology at the Vrije Universiteit Brussel (Belgium). Her research specifically focuses on questions concerning juvenile justice systems and children's rights, in Belgium and in Europe, both in contemporary times and in the past (20th century). 